\title{
Correction to: Characterization of novel pollen-expressed transcripts reveals their potential roles in pollen heat stress response in Arabidopsis thaliana
}

\author{
Nicholas Rutley ${ }^{1} \oplus \cdot$ Laetitia Poidevin $^{2} \oplus \cdot$ Tirza Doniger $^{1} \oplus \cdot$ Richard L. Tillett $^{3,4} \cdot$ Abhishek Rath $^{1} \cdot$ Javier Forment $^{2} \oplus$. \\ Gilad Luria $^{1} \cdot$ Karen A. Schlauch ${ }^{5}$ D . Alejandro Ferrando ${ }^{2}$ D . Jeffery F. Harper ${ }^{3} \cdot$ Gad Miller $^{1}$ (D)
}

Published online: 8 February 2021

(c) The Author(s) 2021

\section{Correction to: Plant Reproduction https://doi.org/10.1007/s00497-020-00400-1}

After publication of the article we found that the Fig. 7 (page 13) should be a part of Supplementary figure.

The original article has been updated.

Open Access This article is licensed under a Creative Commons Attribution 4.0 International License, which permits use, sharing, adaptation, distribution and reproduction in any medium or format, as long as you give appropriate credit to the original author(s) and the source, provide a link to the Creative Commons licence, and indicate if changes were made. The images or other third party material in this article are included in the article's Creative Commons licence, unless indicated otherwise in a credit line to the material. If material is not included in the article's Creative Commons licence and your intended use is not permitted by statutory regulation or exceeds the permitted use, you will need to obtain permission directly from the copyright holder. To view a copy of this licence, visit http://creativecommons.org/licenses/by/4.0/ .

The original article can be found online at https://doi.org/10.1007/ s00497-020-00400-1.

Gad Miller

gad.miller@biu.ac.il

1 The Mina and Everard Goodman Faculty of Life Sciences, Bar Ilan University, 5290002 Ramat-Gan, Israel

2 Instituto de Biología Molecular y Celular de Plantas, Consejo Superior de Investigaciones Cientificas-Universitat Politècnica de València, Valencia, Spain

3 Department of Biochemistry and Molecular Biology, University of Nevada at Reno, Reno, NV 89557, USA

4 Nevada INBRE Bioinformatics Core, University of Nevada at Reno, Reno, NV 89557, USA

5 Institute of Health Innovation, Desert Research Institute, Department of Pharmacology, University of Nevada at Reno, Reno, NV 89557, USA
Publisher's Note Springer Nature remains neutral with regard to jurisdictional claims in published maps and institutional affiliations. 